\title{
Dexamethasone-induced reactivation of bovine herpesvirus type 5 latent infection in experimentally infected rabbits results in a broader distribution of latent viral DNA in the brain
}

\section{S.V. Mayer, V.L. de Quadros, F.S.F. Vogel, E.R. Winkelmann, S. Arenhart, R. Weiblen and E.F. Flores}

\author{
Setor de Virologia, Departamento de Medicina Veterinária Preventiva, \\ Departamento de Microbiologia e Parasitologia, \\ Universidade Federal de Santa Maria, Santa Maria, RS, Brasil
}

\author{
Correspondence \\ E.F. Flores \\ Departamento de Medicina \\ Veterinária Preventiva \\ Universidade Federal de Santa Maria \\ 97105-900 Santa Maria, RS \\ Brasil \\ Fax: +55-55-3220-8034 \\ E-mail: flores@ccr.ufsm.br \\ Research supported by a \\ MCT/CNPq/CAPES/FINEP grant \\ (PRONEX em Virologia Veterinária \\ 215/96). E.F. Flores and R. Weiblen \\ are recipients of $\mathrm{CNPq}$ fellowships \\ (Nos. 520758/96-0 and 520011/95, \\ respectively). S.V. Mayer, \\ V.L. de Quadros, E.R. Winkelmann, \\ and S. Arenhart are recipients \\ of student fellowships from CNPq. \\ $\ldots \ldots \ldots \ldots \ldots \ldots \ldots$
}

Received March 15, 2005 Accepted November 17, 2005 $\ldots \ldots \ldots \ldots \ldots \ldots \ldots$

\begin{abstract}
Bovine herpesvirus type 5 (BHV-5) is a major agent of meningoencephalitis in cattle and establishes latent infections mainly in sensory nerve ganglia. The distribution of latent BHV-5 DNA in the brain of rabbits prior to and after virus reactivation was studied using a nested PCR. Fifteen rabbits inoculated intranasally with BHV-5 were euthanized 60 days post-inoculation (group $\mathrm{A}, \mathrm{N}=8$ ) or submitted to dexamethasone treatment $\left(2.6 \mathrm{mg} \mathrm{kg}{ }^{-1} \mathrm{day}^{-1}\right.$, im, for 5 days $)$ and euthanized 60 days later (group B, N =7) for tissue examination. Two groups of BHV-1-infected rabbits $(\mathrm{C}, \mathrm{N}=3$ and $\mathrm{D}, \mathrm{N}=3)$ submitted to each treatment were used as controls. Viral DNA of group A rabbits was consistently detected in trigeminal ganglia $(8 / 8)$, frequently in cerebellum (5/8), anterior cerebral cortex and pons-medulla (3/8) and occasionally in dorsolateral (2/8), ventrolateral and posterior cerebral cortices, midbrain and thalamus (1/8). Viral DNA of group B rabbits showed a broader distribution, being detected at higher frequency in ventrolateral (6/7) and posterior cerebral cortices (5/7), pons-medulla (6/7), thalamus (4/7), and midbrain (3/7). In contrast, rabbits inoculated with BHV-1 harbored viral DNA almost completely restricted to trigeminal ganglia and the distribution did not change post-reactivation. These results demonstrate that latency by BHV-5 is established in several areas of the rabbit's brain and that virus reactivation leads to a broader distribution of latent viral DNA. Spread of virus from trigeminal ganglia and other areas of the brain likely contributes to this dissemination and may contribute to the recrudescence of neurological disease frequently observed upon BHV-5 reactivation.
\end{abstract}

Key words

- Bovine herpesvirus type 5

- BHV-5

- BHV-1

- Latent infection

- Rabbits

- Brain 


\section{Introduction}

The establishment of latent infection in neurons of sensory and autonomic nerve ganglia is the hallmark of infection by human and animal $\alpha$-herpesviruses and has profound implications in the epidemiology and pathogenesis of these conditions (1). Viral reactivation and shedding may occur under natural or induced stimuli, favoring viral transmission and spread (2). Recrudescence of clinical disease (orolabial, nasal and genital lesions, encephalitis) is a well-documented consequence of reactivation of human and some animal herpesviruses (3-5).

Bovine herpesvirus type 5 (BHV-5) is an $\alpha$-herpesvirus associated with severe, usually fatal meningoencephalitis in cattle $(1,6)$. The disease is characterized by tremors, nystagmus, tooth grinding, circling, ataxia, recumbency, paddling, and death $(5,7)$. Severe outbreaks of neurological disease by BHV -5 have been frequently reported mainly in Brazil and Argentina $(7,8)$. In animals surviving acute infection, BHV-5 establishes a lifelong latent infection that can be reactivated under certain natural or induced stimuli $(4,5)$. In contrast to many other animal herpes virus infections, BHV-5 reactivation is frequently accompanied by recrudescence of clinical disease, both in the natural host and in a rabbit model $(4,5)$.

The major sites of latent infection by human (i.e., herpes simplex virus 1) and animal $\alpha$-herpesviruses (BHV-5, BHV-1, pseudorabies virus) are the sensory nerve ganglia innervating the site of primary viral replication (2,9-11). Therefore, oronasal infection results in the establishment of latency mainly in trigeminal ganglia (TG) and genital infection ensues, with colonization of sacral ganglia with latent viral DNA (2,912). However, other possible neural and nonneural sites of latent infection by, or persistence of, these viruses have also been described (13-15). The major sites of latent infection by BHV-1 are also the sensory nerve ganglia, where the virus replicates lytically during acute infection $(2,14)$. In addition, BHV-1 DNA has been detected in tonsils, in $\mathrm{CD}_{4}+\mathrm{T}$ lymphocytes and in peripheral blood mononuclear cells of latently infected animals $(16,17)$. After experimental genital infection, latent BHV-1 DNA was consistently found in sacral ganglia of heifers (18) and in sacral and other nerve ganglia and in regional lymph nodes of bulls (12). The biological significance of latent infection in non-neural sites and neural sites other than sensory nerve ganglia remains obscure since reactivation from these sites has not been unequivocally demonstrated.

BHV-5 is very neuroinvasive and neurovirulent in both the natural host (19-21) and in animal models (4,21-24). The ensuing neurological disease is often fatal, yet cases of mild infection followed by clinical recovery or even subclinical neurological infection seem not to be rare $(4,5,19,20)$. Natural and/or dexamethasone(Dx)-induced BHV-5 reactivation in calves and rabbits is followed by virus shedding and frequently by recrudescence of neurological disease $(4,5,21)$. Recently, we demonstrated that, in addition to TG, BHV-5 does establish latent infection in several areas of the brain of experimentally inoculated calves (25). Furthermore, reactivation of latent infection was followed by a wider distribution of the virus in the brain and establishment of latency in additional sites (25). The dissemination of the virus to other sites in the brain upon reactivation is believed to play a role in human encephalitis by herpes simplex virus $1(3,15)$ and may be determinant in the recrudescence of neurological disease frequently observed in calves and rabbits latently infected with BHV-5 $(4,5,21)$.

Rabbits have been successfully used to study several aspects of acute and latent BHV-5 infections $(4,21,26)$. In the present study, we determined the distribution of latent BHV-5 DNA in the brain of experimentally infected rabbits before and after Dx- 
induced reactivation, in order to determine whether reactivation of latent viral DNA can lead to the establishment of latency in other brain regions. Our results are consistent with those observed in cattle (25) and indicate the biological importance of latent infection in neural sites other than the TG in the pathogenesis of herpesvirus encephalitis upon reactivation.

\section{Material and Methods}

\section{Experimental design}

Twenty-four rabbits were divided into four groups (A, B, C, D) and inoculated intranasally with BHV-5 (groups A and B) or BHV-1 (groups C and D). Animals were monitored clinically during the acute infection and virus replication was monitored by testing nasal swabs for infectivity. Sixty days after inoculation, rabbits from groups A and $\mathrm{C}$ were euthanized for collection of brain tissue. The other rabbits (groups B and D) were treated with Dx to reactivate the infection and euthanized 60 days later for tissue collection. The distribution of latent viral DNA in different sections of the brain of rabbits of all groups was investigated by nested PCR, using a set of primers for the glycoprotein $\mathrm{B}(\mathrm{gB})$ gene.

\section{Cells and viruses}

A bovine cell line named CRIB (24), derived from Madin-Darby bovine kidney cells (American Type Culture Collection, CCL-22, Rockville, MD, USA) was used for virus multiplication, quantitation and isolation from nasal swabs and tissues. Cells were routinely maintained in Eagle's minimal essential medium (Cultilab, Campinas, $\mathrm{SP}$, Brazil) containing $1.6 \mathrm{mg} / \mathrm{L}$ penicillin, $0.4 \mathrm{mg} / \mathrm{L}$ streptomycin, and $5 \%$ fetal calf serum (Cultilab). The BHV-1 SV-265 strain was isolated from a calf with respiratory disease and the BHV-5 SV-507 strain was isolated from an outbreak of meningoencephalitis in Southern Brazil and has been submitted to nucleotide sequencing of the entire DNA genome (27).

\section{Animals, virus inoculation and \\ dexamethasone treatment}

Twenty-eight weanling New Zealand rabbits (30 to 35 days old, 400 to $600 \mathrm{~g}$ each), of both sexes, seronegative to BHV-5 and BHV1 by virus neutralizing assay, were used for virus inoculation. The inoculated groups were kept in separate cages in an animal isolation facility of the Federal University of Santa Maria (UFSM, building \#20, room 4006). The rabbits were inoculated by the intranasal route with $0.5 \mathrm{~mL}$ of viral suspension in each nostril (total viral dose: $10^{7} \mathrm{TCID}_{50}$ / animal), with the respective virus as follows: group A: BHV-5, $\mathrm{N}=11$; group B: BHV-5, $\mathrm{N}=7$; group $\mathrm{C}$ : $\mathrm{BHV}-1, \mathrm{~N}=3$; group $\mathrm{D}$ : $\mathrm{BHV}-1, \mathrm{~N}=3$. Four rabbits were inoculated with tissue culture medium and served as controls. For virus inoculation, rabbits were previously anesthetized by intramuscular administration of $2 \mathrm{mg}$ Tiletamine/Zolazepan (Zoletil, Virbac, Carros-Cedex, France). Sixty days post-inoculation (pi), animals of groups $\mathrm{A}$ and $\mathrm{C}$ and 2 control rabbits were euthanized for tissue collection. Euthanasia was performed by exsanguination in previously anesthetized animals, according to the protocol described above. Rabbits of groups $\mathrm{B}$ and $\mathrm{D}$ were submitted to daily administrations of Dx (2.6 mg kg-1 day ${ }^{-1}, i m$, for 5 days) starting at day 60 pi (4). The Dx-treated rabbits and 2 control rabbits were euthanized at day 60 post-Dx (pDx) for tissue collection. All procedures of animal handling and experimentation were performed according to the recommendations of the Brazilian College on Animal Experimentation (COBEA; law \#6.638 of May 8th, 1979 - Ethics Principles for Animal Experimentation). The animal experiments were approved by an institutional Ethics and Animal Welfare 
Figure 1. Rabbit brain showing the sections examined by nested PCR for the presence of latent bovine herpesvirus type 1 and 5 DNA. $A$, Dorsal view; $B$, sagittal view. $\mathrm{cb}=$ cerebellum; $\mathrm{pc}=$ posterior cerebral cortex; dlc $=$ dorsolateral cerebral cortex; ac $=$ anterior cerebral cortex; th $=$ thalamus; $\mathrm{mb}=$ midbrain; $\mathrm{vlc}=$ ventrolateral cerebral cortex; po $=$ pons-medulla; $\mathrm{mo}=$ medulla oblongata. Olfactory bulb (ol) and trigeminal ganglia ( $\mathrm{tg}$ ) are not shown.
Committee (Comitê de Ética e Bem-Estar Animal - UFSM, approval \#09/2005; process \#23081.013613/2005-72).

\section{Animal monitoring, sample collection and processing}

After virus inoculation and Dx treatment, rabbits were monitored clinically on a daily basis. Once the clinical signs of neurological disease appeared, clinical monitoring was performed twice a day. Nasal swabs for viral isolation were collected daily up to the day of Dx administration from animals of groups $A$ and $\mathrm{C}$, and then up to the day of euthanasia in group B and D rabbits. The swabs were immersed in $1 \mathrm{~mL}$ Eagle's minimal essential medium containing $5 \mathrm{X}$ penicillin and stored at $-70^{\circ} \mathrm{C}$. After thawing and centrifugation at $3,000 \mathrm{~g}$ for $10 \mathrm{~min}$, the supernatants were inoculated onto monolayers of CRIB cells grown in 24-well plates and submitted to three passages of five days each, with cells being monitored for cytopathic effect. At autopsy, different sections of the brain and
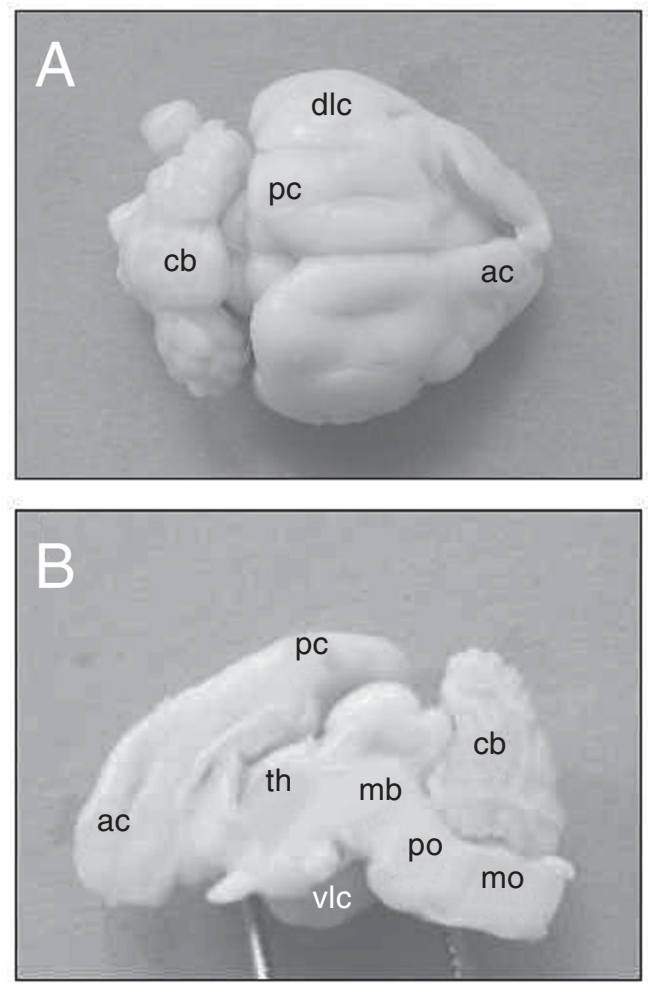

the TG were collected aseptically and individually for virus isolation and PCR.

The following structures were collected with individual disposable scalpel blades and plastic forceps: cerebral cortex (anterior, posterior, ventrolateral, and dorsolateral), olfactory bulb, thalamus, midbrain, pons-medulla oblongata, cerebellum, and TG. Once sectioned, each structure was placed in individual plastic bags. The location of the sections examined for the presence of viral DNA is depicted in Figure 1. Tissue collection was performed bilaterally when applicable. Virus isolation was only attempted in sections that were positive for viral DNA by PCR. For virus isolation, the tissue samples were processed by preparing a $10 \%(w / v)$ homogenized suspension, which was inoculated onto CRIB monolayers. Monitoring of virus replication was performed as described above.

\section{DNA extraction}

Total DNA for PCR was extracted from approximately $0.2 \mathrm{~g}$ of each section. Template DNA was prepared by using the EasyDNA Isolation Kit (Invitrogen, Carlsbad, CA, USA) according to the manufacturer protocol. The DNA concentration was measured by UV absorbance at $260 \mathrm{~nm}$. For large areas (dorsolateral, ventrolateral and cerebellum cortices, for example), representative fragments were collected bilaterally, pooled and submitted to DNA extraction.

\section{Nested polymerase chain reaction}

PCR was performed using two sets of primers corresponding to positions 57,338 and 57,782 (primers 1 and 2) and 57,143 and 57,416 (primers 3 and 4) of the $\mathrm{gB}$ genecoding region of the BHV-5 strain SV-507 (27). The target region (273 bp) was initially amplified with the external primers: (forward) 5'-CCAGTCCAGGCAACCGTCAC-3' (position 57,338) and (reverse) 5'-CTCGAAAG 
CCGAGTACCTGCG-3' (position 57,782) and then with the internal primers: (forward) 5'GTGGTGGCCTTTGACCGCGAC-3' (position 57,143) and (reverse) 5'-GCTCCGGCG AGTAGCTGGTGTG-3' (position 57,416). These two sets of primers recognize the homologous sequence of $\mathrm{gB}$ of BHV-1 (E.F. Flores, personal communication). PCR was performed in $25 \mu \mathrm{L}$ using $1 \mu \mathrm{L}$ template DNA (containing approximately $1 \mu \mathrm{g}$ total DNA in TE buffer), $100 \mathrm{ng}$ of each primer, $1 \mathrm{mM}$ $\mathrm{MgCl}_{2}, 10 \mathrm{mM}$ dNTPs, $10 \%$ DMSO, $1 \mathrm{X}$ reaction buffer, and 0.5 units of Taq polymerase (Gibco BRL, Grand Island, NY, USA). The PCR conditions were: initial denaturation at $94^{\circ} \mathrm{C}$ for $10 \mathrm{~min}$, followed by 35 cycles of $94^{\circ} \mathrm{C}$ for $1 \mathrm{~min}$ and $56^{\circ} \mathrm{C}$ for $40 \mathrm{~s}$ for primer annealing and $72^{\circ} \mathrm{C}$ for $40 \mathrm{~s}$ for primer extension, and a final extension of $7 \mathrm{~min}$ at $72^{\circ} \mathrm{C}$. The second PCR was performed using $2 \mu \mathrm{L}$ of PCR products from the first PCR. The final product obtained was an amplicon of $273 \mathrm{bp}$. PCR products were submitted to electrophoresis on $1.5 \%$ agarose gel, stained with ethidium bromide and visualized under UV light. DNA extracted from the brain of mock-inoculated rabbits was used as negative control. DNA extracted from the brain of a calf acutely infected with BHV-5 was used as positive control. The specificity of PCR amplification was confirmed in a previous report (25).

\section{Results}

\section{Acute infection}

All rabbits inoculated with BHV-5 (groups A and B) excreted virus in nasal secretions up to day $7 \mathrm{pi} ; 4$ were still shedding virus at day 9 pi and 3 at day 10 pi. Virus shedding stopped after day 10 pi. Thereafter, a few rabbits shed virus for one day sporadically within the interval between days 19 and 60 pi. No virus shedding was detected on the days preceding Dx treatment, demonstrating that rabbits were latently infected. Three rabbits (\#9, 3 and 5) developed signs of neurological disease and died or were euthanized in extremis at days 15 , 20, and $21 \mathrm{pi}$, respectively. The signs observed were excitation/depression, seizures, tremors, grinding of the teeth, opisthotonus, rear limb paralysis, and severe depression. Infectious virus was detected in several areas of the brain of these animals. The rabbits that died with neurological disease during acute infection were not included in the study. Rabbits inoculated with BHV-1 shed virus in nasal secretions up to day 9 pi; one was still shedding at day 11 pi. No virus shedding was detected thereafter and up to Dx treatment (day 60 pi). Control rabbits did not shed virus in any swab collection.

\section{Latent infection}

At day 60 pi (and on days preceding it), no infectious virus was detected in nasal swabs collected from the four groups. Thus, these animals fulfilled the classical definition of latent infection. At day $60 \mathrm{pi}$, group $\mathrm{A}$ (BHV-5) and $\mathrm{C}$ (BHV-1) rabbits were euthanized and several brain sections were collected to investigate the distribution of latent viral DNA by nested PCR. The results of nested PCR performed on total DNA extracted from these brain sections are presented in Tables 1 and 2; representative nested

Table 1. Detection of bovine herpesvirus 5 DNA by PCR in brain sections of rabbits 60 days after intranasal inoculation (group A).

\begin{tabular}{|c|c|c|c|c|c|c|c|c|c|c|}
\hline \multirow[t]{2}{*}{ Animal No. } & \multicolumn{10}{|c|}{ Area } \\
\hline & ol & ac & vlc & dlc & $\mathrm{pc}$ & $\mathrm{cb}$ & $\operatorname{tg}$ & po & $\mathrm{mb}$ & th \\
\hline 7 & - & - & - & + & - & + & + & - & - & - \\
\hline 11 & - & - & - & - & - & + & + & + & - & - \\
\hline 12 & - & + & - & - & - & - & + & - & - & - \\
\hline 16 & - & - & - & - & - & - & + & - & - & - \\
\hline 18 & - & + & - & + & + & + & + & + & + & + \\
\hline 20 & - & - & - & - & - & - & + & - & - & - \\
\hline 22 & - & + & - & - & - & + & + & - & - & - \\
\hline 24 & - & - & + & - & - & + & + & + & - & - \\
\hline
\end{tabular}

ol $=$ olfactory bulb; cerebral cortices: $\mathrm{ac}=$ anterior; $\mathrm{vlc}=$ ventrolateral; $\mathrm{dlc}=$ dorsolat eral; $\mathrm{pc}=$ posterior; $\mathrm{cb}=$ cerebellum; $\mathrm{tg}=$ trigeminal ganglia; $\mathrm{po}=$ pons-medulla; $\mathrm{mb}=$ midbrain; th $=$ thalamus; $-=$ negative result; $+=$ positive result. 
PCR results are shown and Figures 2 and 3. BHV-5 DNA was consistently detected in TG (8/8), frequently in the cerebellum (5/8), occasionally in the pons-medulla and anterior cerebral cortex (3/8), dorsolateral cere-

Table 2. Detection of bovine herpesvirus 1 DNA by PCR in brain sections of rabbits 60 days after intranasal virus inoculation (group $\mathrm{C}$ ) and 60 days after dexamethasoneinduced virus reactivation (group D).

\begin{tabular}{|c|c|c|c|c|c|c|c|c|c|c|}
\hline \multirow[t]{2}{*}{ Animal No. } & \multicolumn{10}{|c|}{ Area } \\
\hline & ol & $\mathrm{ac}$ & vlc & dlc & $\mathrm{pc}$ & $\mathrm{cb}$ & $\operatorname{tg}$ & po & $\mathrm{mb}$ & th \\
\hline \multicolumn{11}{|l|}{ Group C } \\
\hline 15 & - & - & - & - & - & - & + & + & - & - \\
\hline 17 & - & - & - & + & - & + & + & + & - & - \\
\hline 19 & - & - & - & - & - & - & + & - & - & - \\
\hline \multicolumn{11}{|l|}{ Group D } \\
\hline 13 & - & - & - & - & + & - & + & + & - & - \\
\hline 26 & - & - & - & - & + & - & + & - & + & - \\
\hline 28 & - & - & - & - & - & + & + & - & - & - \\
\hline
\end{tabular}

Virus reactivation with dexamethasone was induced 60 days after virus inoculation. ol = olfactory bulb; cerebral cortices: $\mathrm{ac}=$ anterior; $\mathrm{vlc}=$ ventrolateral; $\mathrm{dlc}=$ dorsolateral; $\mathrm{pc}=$ posterior; $\mathrm{cb}=$ cerebellum; $\mathrm{tg}=$ trigeminal ganglia; $\mathrm{po}=$ pons-medulla; $\mathrm{mb}=$ midbrain; th $=$ thalamus; $-=$ negative result; $+=$ positive result.
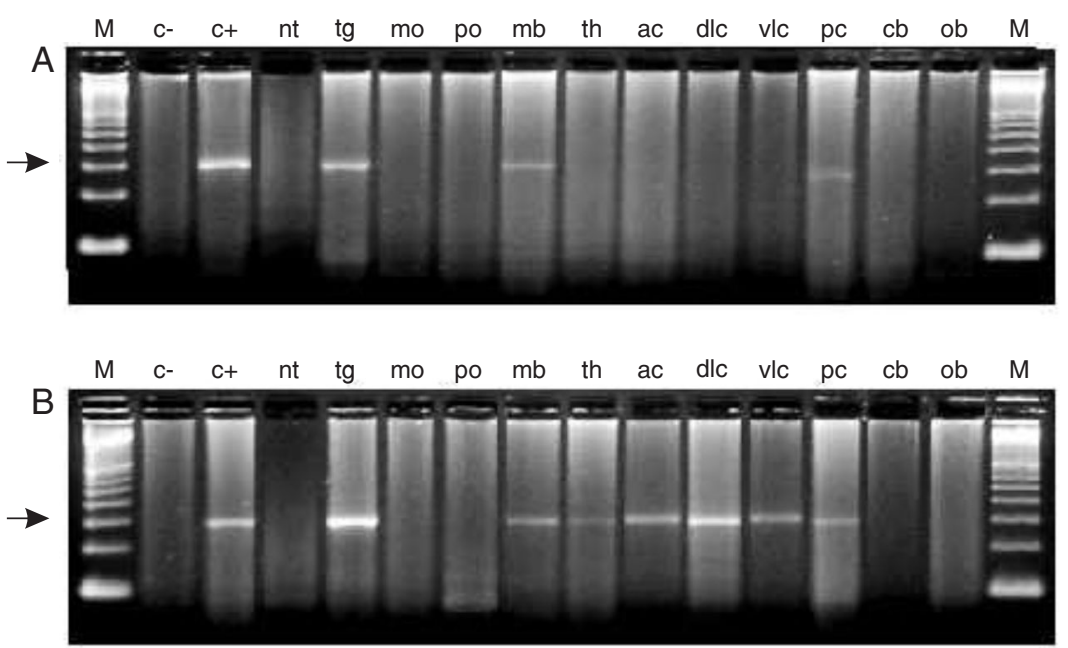

Figure 2. Detection of bovine herpesvirus type 5 DNA in the brain of experimentally infected rabbits before (top) and after (bottom) dexamethasone-induced viral reactivation. $A$, Brain sections of rabbit \#7 (group A); $B$, brain sections of rabbit \#6 (group B). The lanes of both panels show: $\mathrm{M}=$ molecular weight marker (100-bp ladder); $\mathrm{c}-=$ negative control; $\mathrm{C}^{+}=$ positive control; $\mathrm{nt}=\mathrm{no}$ template; $\mathrm{tg}=$ trigeminal ganglia; $\mathrm{mo}=$ medulla oblongata; $\mathrm{po}=$ pons-medulla; $\mathrm{mb}=$ midbrain; th $=$ thalamus; $\mathrm{ac}=$ anterior cerebral cortex; dlc $=$ dorsolateral cerebral cortex; vlc $=$ ventrolateral cerebral cortex; $\mathrm{pc}=$ posterior cerebral cortex; $\mathrm{cb}=$ cerebellum; ob = olfactory bulb. PCR products were submitted to electrophoresis on $1.5 \%$ agarose gel, stained with ethidium bromide, and visualized under UV light. The size of amplified products ( $273 \mathrm{bp}$ ) is indicated by arrows. bral cortex (2/8), thalamus, ventrolateral and posterior cerebral cortices, and midbrain (1/ 8) of group A rabbits (Table 1 and Figure 2). In contrast, in group $\mathrm{C}$ rabbits BHV-1 DNA was detected consistently in TG, and only occasionally found in other sections (Table 2, Figure 3). All DNA-positive tissues were negative for virus isolation, confirming that the rabbits were latently infected. Total DNA extracted from the brain of two rabbits used as controls gave negative results in nested PCR.

To determine whether the distribution of latent viral DNA in the brain would change after virus reactivation, rabbits from groups B (BHV-5) and D (BHV-1) were submitted to five daily administrations of Dx beginning at day 60 pi. Following Dx treatment, all group B rabbits shed virus in nasal secretions, starting at day $3 \mathrm{pDx}$ and lasting 4 to 11 days. All group D rabbits also excreted virus after Dx treatment, with shedding starting at day $4 \mathrm{pDx}$ and lasting 7 to 9 days. At day $60 \mathrm{pDx}$, rabbits from both groups were euthanized for tissue collection. At the time of tissue collection, no animal was shedding virus. The distribution of latent viral DNA in the brain of BHV-5-infected rabbits, after Dx treatment, is shown in Table 3 and Figure 2. Briefly, viral DNA was detected in roughly the same areas of group A rabbits, yet with higher frequency in several sections, mainly in ventrolateral (6/7) and posterior cerebral cortices (5/7), pons-medulla (6/7), thalamus (4/7), and midbrain (3/7). The sections showing the highest increase in positivity were the ventrolateral cerebral cortex (1/8 to $6 / 7)$, posterior cerebral cortex (1/8 to $5 / 7)$, ponsmedulla (3/8 to $6 / 7)$, thalamus (1/8 to $4 / 7)$, and midbrain (1/8 to $3 / 7)$. The other sections showed a roughly similar frequency of latent viral DNA in both groups. Compared to group A, group B rabbits showed an almost two-fold increase in the number of total DNA-positive sections (38/70 or $54.3 \%$ positive sections against $25 / 80$ or $31.2 \%$ ). Likewise, rabbits from group B showed a higher 
mean number of PCR-positive sections (mean: 5.6 vs 3.1). Again, in group D rabbits (BHV-1), latent viral DNA was practically limited to TG, with only a few other sections being positive. All PCR-positive sections were negative for virus isolation, fulfilling the classical requirements for defining latent infection. No DNA-positive section was ever found in the brain of two control, mockinoculated rabbits.

\section{Discussion}

The present results confirm and extend our findings in rabbits in which BHV-5 DNA was detected in several different areas of the brain of experimentally infected calves (25). In the present study, BHV-5 DNA was detected in several areas of the brain of latently infected rabbits prior to Dx-induced reactivation. Furthermore, examination of brain sections of rabbits 60 days after Dx administration demonstrated a broader distribution of viral DNA in different regions of the brain. In particular, the ventrolateral, posterior cerebral cortices and pons-medulla showed an increased frequency of colonization with latent viral DNA after virus reactivation. The failure to demonstrate infectious virus in PCR-positive tissues is consistent with the biological criteria traditionally used to define latent infection: presence of viral DNA in the absence of productive viral replication $(2,14,15)$. Taken together, these results demonstrate that further viral dissemination within the brain may occur upon reactivation and indicate a potential role of latency in central nervous system (CNS) sites, not excluding the TG, in the pathogenesis of recrudescent neurological disease that frequently accompanies BHV-5 reactivation. Our findings also demonstrate that the biology of latent infection of BHV-5 in rabbits resembles that in the natural host, thus validating the use of this species as a laboratory model to study different aspects of BHV-5 pathogenesis.
Sensory nerve ganglia are the major sites of latent infection by human and animal $\alpha$ herpesviruses, but additional sites of latency have been identified for herpes simplex virus 1, pseudorabies virus, and BHV-1 (3,911,13-17). The biological significance of latency in non-neural sites and in neural sites
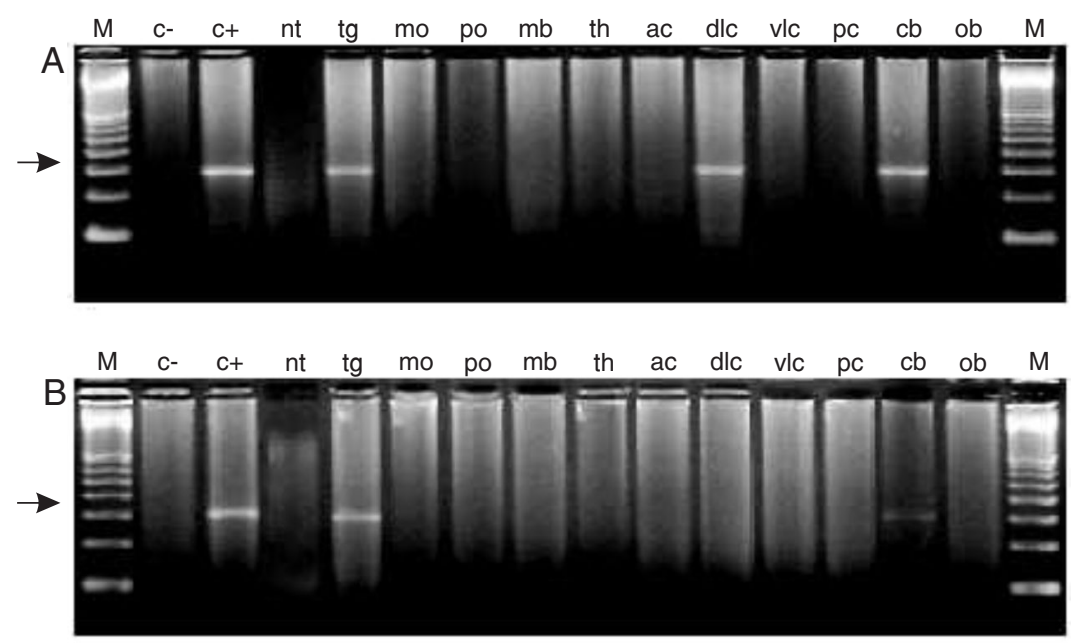

Figure 3. Detection of bovine herpesvirus type 1 DNA in the brain of experimentally infected rabbits before (top) and after (bottom) dexamethasone-induced viral reactivation. $A$, Brain section of rabbit \#15 (group C); $B$, brain section of rabbit \#28 (group D). The lanes of both panels show: M, molecular weight marker (100-bp ladder); $\mathrm{c}^{-}=$negative control; $\mathrm{c}+=$ positive control; $\mathrm{nt}=$ no template; $\mathrm{tg}=$ trigeminal ganglia; $\mathrm{mo}=$ medulla oblongata; $\mathrm{po}=$ pons-medulla; $\mathrm{mb}=$ midbrain; th $=$ thalamus; $\mathrm{ac}=$ anterior cerebral cortex; dlc $=$ dorsolateral cerebral cortex; vlc $=$ ventrolateral cerebral cortex; $\mathrm{pc}=$ posterior cerebral cortex; $\mathrm{cb}=$ cerebellum; ob = olfactory bulb. PCR products were submitted to electrophoresis on $1.5 \%$ agarose gel, stained with ethidium bromide, and visualized under UV light. The size of amplified products ( $273 \mathrm{bp})$ is indicated by arrows.

Table 3. Detection of bovine herpesvirus 5 DNA by PCR in brain sections of rabbits 60 days after dexamethasone-induced virus reactivation (group B).

\begin{tabular}{|c|c|c|c|c|c|c|c|c|c|c|}
\hline \multirow[t]{2}{*}{ Animal No. } & \multicolumn{10}{|c|}{ Area } \\
\hline & ol & ac & vlc & dlc & $\mathrm{pc}$ & $\mathrm{cb}$ & $\operatorname{tg}$ & po & $\mathrm{mb}$ & th \\
\hline 1 & - & - & - & - & + & - & + & + & - & - \\
\hline 2 & - & - & + & - & - & + & + & + & - & - \\
\hline 4 & - & + & + & - & + & + & + & + & - & - \\
\hline 6 & - & + & + & + & + & - & + & - & + & + \\
\hline 8 & - & - & + & - & - & - & + & + & - & + \\
\hline 10 & - & + & + & + & + & - & + & + & + & + \\
\hline 14 & - & - & + & + & + & - & + & + & + & + \\
\hline
\end{tabular}

Virus reactivation with dexamethasone was induced 60 days after virus inoculation. ol = olfactory bulb; cerebral cortices: $\mathrm{ac}=$ anterior; vlc = ventrolateral; dlc = dorsolateral; $\mathrm{pc}=$ posterior; $\mathrm{cb}=$ cerebellum; $\mathrm{tg}=$ trigeminal ganglia; $\mathrm{po}=$ pons-medulla; $\mathrm{mb}=$ midbrain; th = thalamus; $-=$ negative result; $+=$ positive result. 
other than the TG is controversial since attempts to reactivate the virus from some of these tissues by explant cultures have failed (13-17).

Previous studies have detected latent BHV-5 DNA in some areas of the brain of experimentally infected calves $(9,20)$. Furthermore, we recently demonstrated that BHV-5 does establish latency in several areas of the brain of experimentally infected calves and that the distribution of latent DNA changes after virus reactivation, resulting in colonization of additional sites (25). The biological significance of the presence of viral DNA in several areas of the brain during latent infection, and the possible implications for the pathogenesis of BHV-5 infection are unclear at this point. However, colonization of deep areas of the brain with latent viral DNA may have important implications for the pathogenesis of BHV-5 neurological disease that frequently occurs after reactivation $(4,5,21,25)$. It is conceivable that virus reactivating from deep areas of the brain, in addition to virus reactivating from the TG, may serve as a source of virus for neurological infection during reactivation. In support of this explanation was the recent demonstration that the timing, kinetics and distribution of histological changes in the CNS after BHV-5 reactivation differed from those observed during acute infection $(4,5,21)$.

In the present study, latent BHV-5 DNA showed an irregular distribution even among rabbits of the same group. However, comparison between groups A versus B demonstrated a clear tendency of increasing colonization of CNS sites after reactivation. In group A, 2 rabbits (\#16 and 20) harbored BHV-5 DNA exclusively in TG, 5 showed positivity in one (\#12), two $(\# 7,11,22)$ or three sections (\#24) besides the TG, and 1 rabbit (\#18) showed a broad distribution of BHV-5 DNA in the brain. In comparison, among rabbits submitted to Dx administration prior to PCR examination (group B), none harbored BHV-5 DNA exclusively in the TG, only 1 (\#1) had two additional sites, 2 showed DNA in three additional sites (\#2, 8 ), and 4 rabbits (\#4, 6, 10, and 14) showed a broad distribution of latent DNA in the brain (four to seven positive areas in addition to TG). These findings unequivocally show that the distribution of latent BHV-5 DNA changes by becoming more broadly distributed in regions of the brain following virus reactivation. In particular, the ventrolateral and posterior cortices and the ponsmedulla showed the most largest increase in the frequency of viral DNA detection from pre- to post-reactivation. Thus, reactivating virus from TG and also from other areas found to harbor viral DNA prior to reactivation (i.e., pons-medulla, cerebral cortex, midbrain, thalamus) possibly contributed to the secondary invasion of the brain occurring upon reactivation. However, it will be necessary to demonstrate that BHV-5 DNA in CNS sites is biologically active, i.e., it can be reactivated as the DNA in the TG, for example, to support this explanation.

In contrast, the distribution of latent BHV1 DNA was more restricted, regardless of whether the examination was performed in rabbits submitted or not to virus reactivation. These findings are also consistent with results of previous studies which showed that TG is a major site of BHV-1 latency in the natural hosts $(2,9,14,18)$ and in rabbits used as a model $(4,28)$. Nevertheless, a few other brain areas also harbored latent DNA, indicating that BHV-1 is capable of invading some brain regions during acute infection and subsequently to establish latency. Indeed, in a parallel experiment, we were able to detect infectious virus in some areas of the brain of rabbits inoculated with a BHV-1 isolate (data not shown). These data indicate that BHV-1, although it is not as neuroinvasive as BHV-5, may be able to reach some areas of the brain after intranasal inoculation. The replication and spread within the brain, however, would not suffice to produce clinical meningoencephalitis, ex- 
plaining why BHV-1 is rarely associated with neurological disorders in cattle and in experimentally infected rabbits $(4,20,21,23$, 26).

Our results with rabbits agree with findings in cattle and indicate that BHV-5 does establish latent infection in several areas of the brain and that Dx-induced reactivation results in a broader distribution of the latent DNA in the brain. The biological significance of these additional sites of latency is unknown and deserves further investigation.

\section{References}

1. Roizman B (1992). The family Herpesviridae: an update. Archives of Virology, 123: 432-445.

2. Rock DL (1994). Latent infection with bovine herpesvirus type-1. Seminars in Virology, 5: 233-240.

3. Whitley R, Lakemann AD, Nahmias A et al. (1982). DNA restriction analysis of herpes simplex virus isolates obtained from patients with encephalitis. New England Journal of Medicine, 307: 1060-1082.

4. Caron L, Flores EF, Scherer CFC et al. (2002). Latent infection by bovine herpesvirus type- 5 in experimentally infected rabbits: virus reactivation, shedding and recrudescence of neurological disease. Veterinary Microbiology, 4: 285-295.

5. Perez SE, Bretschneider MR, Leunda FA et al. (2002). Primary infection, latency and reactivation of bovine herpesvirus type 5 in the bovine nervous system. Veterinary Pathology, 39: 437-444.

6. Studdert MJ (1989). Bovine encephalitis herpesvirus. Veterinary Record, 125: 584

7. Carrillo BJ, Ambrogi A, Schudel AA et al. (1983). Meningoencephalitis caused by IBR virus in calves in Argentina. Zentralblatt für Veterinaermedizin. Reihe B, 30: 327-332.

8. Salvador SC, Lemos RAA, Riet-Correa F et al. (1998). Meningoencefalite em bovinos causada por herpesvírus no Mato Grosso do Sul e São Paulo. Pesquisa Veterinária Brasileira, 18: 76-83.

9. Ashbaugh SE, Thompson KE, Belknap EB et al. (1997). Specific detection of shedding and latency of bovine herpesvirus 1 and 5 using a nested polymerase chain reaction. Journal of Veterinary Diagnostic Investigation, 9: 387-394.

10. Cheung AK (1995). Investigation of pseudorabies virus DNA and RNA in trigeminal ganglia and tonsil tissues of latently infected swine. American Journal of Veterinary Research, 56: 45-50.

11. Rziha JH, Mettenleiter TC, Ohlinger $V$ et al. (1986). Herpesvirus (pseudorabies virus) latency in swine: occurrence and physical state of viral DNA in neural tissues. Virology, 155: 600-613.

12. Vogel FSF, Flores EF, Weiblen R et al. (2004). Intrapreputial infection of young bulls with bovine herpesvirus type 1.2: acute balanoposthitis, latent infection and detection of viral DNA in regional neural and non-neural tissues 50 days after experimental reactivation. Veterinary Microbiology, 98: 185-196.

13. Croen KD (1991). Latency of human herpesvirus. Annual Review of Medicine, 42: 61-67.

14. Jones C (1998). Alpha-herpesvirus latency: its role in disease and survival of the virus in nature. Advances in Virus Research, 51: 4799.

15. Steiner I \& Kennedy GE (1995). Herpes simplex virus latent infection in the nervous system. Journal of Neurovirology, I: 19-29.
16. Lovato LT, Winkler MT, Stone-Inman M et al. (2000). Detection of bovine herpesvirus type 1 (BHV-1) viral DNA in peripheral blood mononuclear cells (PBMC). Proceedings of the 81st Annual Meeting of the Conference of Research Workers in Animal Disease, Chicago, IL, USA, November 12-14. lowa University Press, Ames, IA, USA.

17. Winkler MT, Doster A \& Jones C (2000). Persistence and reactivation of bovine herpesvirus 1 in the tonsils of infected calves. Journal of Virology, 74: 5337-5346.

18. Ackermann M, Peterhans E \& Wyler R (1982). DNA of bovine herpesvirus type 1 in the trigeminal ganglia of latently infected calves. American Journal of Veterinary Research, 43: 36-40.

19. Belknap EB, Collins JK, Ayers VK et al. (1994). Experimental infection of neonatal calves with neurovirulent bovine herpesvirus type 1.3. Veterinary Pathology, 31: 358-365.

20. Meyer G, Lemaire M, Ros $C$ et al. (2001). Comparative pathogenesis of acute and latent infections of calves with bovine herpesvirus types 1 and 5. Archives of Virology, 146: 633-652.

21. Beltrão N (2000). Herpesvírus bovino tipo 5 (BHV-5): infecção experimental de bovinos e utilização de coelhos como modelo. Master's thesis, Universidade Federal de Santa Maria, Santa Maria, RS, Brazil.

22. Silva AM, Weiblen R, Irigoyen LF et al. (1999). Experimental infection of sheep with bovine herpesvirus type-5 (BHV-5). Veterinary Microbiology, 66: 89-99.

23. Lee BJ, Weiss ML, Mosier D et al. (1999). Spread of bovine herpesvirus type 5 (BHV-5) in the rabbit brain after intranasal inoculation. Journal of Neurovirology, 5: 474-484.

24. Flores EF \& Donis RO (1995). Isolation and characterization of a bovine cell line resistant to infection with the pestivirus bovine viral diarrhea virus (BVDV). Virology, 208: 565-575.

25. Vogel FSF, Caron L, Flores EF et al. (2003). Distribution of bovine herpesvirus type 5 DNA in the central nervous systems of latently, experimentally infected calves. Journal of Clinical Microbiology, 41: $4512-4520$.

26. Chowdhury SI, Lee BJ, Mosier D et al. (1997). Neuropathology of bovine herpesvirus type 5 (BHV-5) meningo-encephalitis in a rabbit seizure model. Journal of Comparative Pathology, 117: 295-310.

27. Delhon G, Moraes MP, Lu Z et al. (2003). Genome of bovine herpesvirus 5. Journal of Virology, 77: 10339-10347.

28. Rock DL, Lokensgard J, Lewis T et al. (1992). Characterization of dexamethasone-induced reactivation of latent bovine herpesvirus 1. Journal of Virology, 66: 2484-2490. 